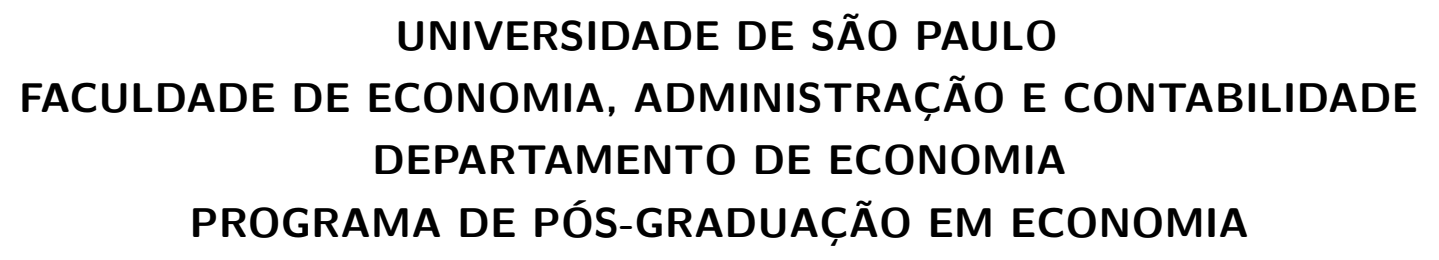

\title{
The Role of Bank Branches in Local Credit Markets: Evidence from Brazil
}

O Papel da Agência Bancária no Mercado Municipal de Crédito: Evidências do Brasil

Mariana Pereira Suplicy

Orientador: Prof. Dr. Gabriel de Abreu Madeira 

Prof. Dr. Marco Antonio Zago

Reitor da Universidade de São Paulo

Prof. Dr. Adalberto Américo Fischmann

Diretor da Faculdade de Economia, Administração e Contabilidade

Prof. Dr. Hélio Nogueira da Cruz

Chefe do Departamento de Economia

Prof. Dr. Márcio Issao Nakane

Coordenador do Programa de Pós-Graduação em Economia 



\title{
MARIANA PEREIRA SUPLICY
}

\section{The Role of Bank Branches in Local Credit Markets: Evidence from Brazil}

O Papel da Agência Bancária no Mercado Municipal de Crédito: Evidências do Brasil

\begin{abstract}
Dissertação apresentada ao Departamento de Economia da Faculdade de Economia, Administração e Contabilidade da Universidade de São Paulo como requisito parcial para a obtenção do título de Mestre em Ciências.
\end{abstract}

Orientador: Prof. Dr. Gabriel de Abreu Madeira

\section{Versão Corrigida}

(versão original disponível na Faculdade de Economia, Administração e Contabilidade) 

FICHA CATALOGRÁFICA

Elaborada pela Seção de Processamento Técnico do SBD/FEA/USP

Suplicy, Mariana Pereira

The role of bank branches in local credit markets: evidence from

Brazil / Mariana Pereira Suplicy. - São Paulo, 2015.

$47 \mathrm{p}$.

Dissertação (Mestrado) - Universidade de São Paulo, 2015.

Orientador: Gabriel de Abreu Madeira.

1. Crédito 2. Acesso a serviços financeiros 3. Agência bancária 4. Banco comercial 5. Desenvolvimento econômico I. Universidade de São Paulo. Faculdade de Economia, Administração e Contabilidade. II. Título.

CDD -332.7 
À minha família

por todo apoio e carinho sempre. 


\section{Agradecimentos}

Aos meus pais, Paulo e Luciana e às minhas irmãs, Joana e Isabel, pela paciência, compreensão e incentivo durante todo o período do mestrado.

Ao meu namorado Guilherme, que participou de incontáveis discussões sobre a dissertação, teve paciência nos momentos necessários e me pressionou quando foi preciso também. Obrigada por todo amor, carinho e apoio.

Ao Professor Gabriel de Abreu Madeira, pela orientação, pelas discussões sobre agências bancárias e sobre a vida em geral, por diminuir minhas angústias de principiante na vida acadêmica. Seus comentários e ativa participação na concepção do trabalho foram essenciais.

Ao Professor Fábio Adriano Miessi Sanches, pela introdução à literatura de OI e por todos os essenciais comentários e sugestões para melhorar o resultado final do trabalho durante todo o processo de elaboração e nas bancas de qualificação e de defesa. Ao Professor Klênio Barbosa pela leitura cuidadosa e preciosos comentários na banca de defesa. Ao Professor Márcio Issao Nakane pelos comentários na banca de qualificação.

À toda a equipe de Economia do Direito da LCA, em especial à Sílvia e ao Ricardo, pelo esforço para acomodar minhas ausências e pelo incentivo durante o percurso.

À turma de mestrado, principalmente Alison, Leonardo, Eugenia, Pedro e Fernando pelas discussões elucidativas e risadas nos preciosos momentos de descontração.

A todos meus amigos que me apoiaram durante todo o mestrado e muitas vezes ajudaram com palpites sobre a dissertação, em especial, Lucas, Giselle, Marcello, João, Carolina, Marina, Fernanda e Rafael.

À Coordenação de Aperfeiçoamento de Pessoal de Nível Superior (CAPES) e à Fundação de Amparo à Pesquisa do Estado de São Paulo (FAPESP) pelo apoio financeiro. 



\section{Resumo}

A Literatura Econômica de desenvolvimento aponta o crédito como um dos determinantes do desenvolvimento econômico, que promove investimentos, suavização do consumo, mitigação do risco e uso de novas tecnologias de produção. O objetivo deste trabalho consiste em analisar se a presença física de bancos por meio da agência bancária ainda é relevante para o desenvolvimento de mercados locais de crédito no Brasil. A relação entre crédito e agências bancárias pode sofrer de endogeneidade, uma vez que existem características de mercado não-observáveis que podem afetar tanto crédito quanto a entrada de bancos nos mercados. Para tratar esta endogeneidade, se propõe o uso de um framework de OI para modelar a decisão de entrada de firmas. A partir destes modelos, utiliza-se o resultado previsto como instrumento para as agências bancárias observadas. O resultado encontrado é de que, ao utilizar o valor esperado de agências ou a probabilidade estimada de haver agência, o impacto de agência em crédito se reduz significativamente e é nulo na maioria das especificações e para a maior parte dos anos da amostra. O uso de um segundo modelo de OI como teste secundário teve o mesmo resultado.

Palavras-chaves: Crédito, Acesso a Serviços Financeiros, Agência Bancária, Banco Comercial, Desenvolvimento Econômico. 



\section{Abstract}

Credit is seen in Economic Literature as one of development drivers, promoting investment, smoothing consumption, allowing for risk sharing and the use of new production technologies. Our objective is to analyze if the physical presence of banks through bank branches is still relevant to develop local credit markets in Brazil. Since there are unobservable market characteristics that could drive both credit and bank entry, the relation between credit and branches may suffer from endogeneity. Therefore, the simple regression of credit on bank branches would be biased. To try to deal with this endogeneity, we employ an IO framework to model firm entry and use the estimated result as an instrument for observed bank branches. We find that estimations using expected values or predicted probabilities of bank branches show little to no effect of bank branches on credit. The same result is achieved when using a second IO model as an additional analysiss.

Keywords: Credit, Access to Financial Services, Bank Branch, Retail Bank, Development. 



\section{Sumário}

1 Introduction . . . . . . . . . . . . . . . . . 19

2 Banking sector and financial deepening in Brazil . . . . . . . . . 23

3 Empirical strategy and data . . . . . . . . . . . . . . 29

3.1 Modeling firm entry and credit market equilibrium under complete infor-

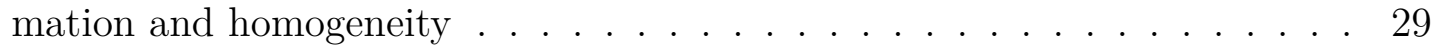

3.2 Data . . . . . . . . . . . . . . . . . . . . . . 31

4 Results . . . . . . . . . . . . . . . . . 35

4.1 First stage: Entry under complete information . . . . . . . . . . . . . . 35

4.2 Second stage: Effects of bank branches on credit . . . . . . . . . . . . . . . 38

5 Additional analysis: Entry under incomplete information . . . . . . . . . . 41

6 Concluding Remarks . . . . . . . . . . . . . . . . . . . . . . 47

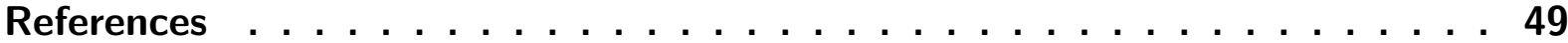

A Maps of Brazilian municipalities by number of private and public bank branches ........................... 51

B Results for incomplete information model applied to the 1,097 markets sample 53 



\section{Lista de ilustrações}

Figura 1 - State-Owned and Private bank Branches in Brazil . . . . . . . . . . . . 23

Figura 2 - Brazilian Municipalities by number of bank branches - 1990, 2003 and

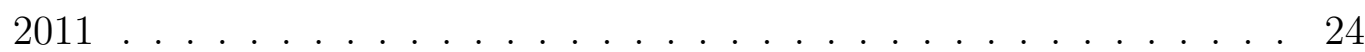

Figura 3 - Brazilian Municipalities by GDP per capita in BRL thousands - 2003

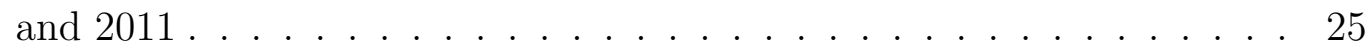

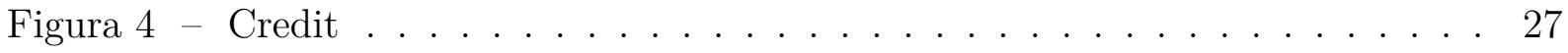

Figura 5 - Kernel density of population (thousands) conditional to the number of bank branches in each municipality . . . . . . . . . . . . . . . . 33

Figura 6 - Kernel density of population (thousands) conditional to the predicted number of bank branches in each municipality according to population thresholds . . . . . . . . . . . . . . . . . . . 37

Figura 7 - Plots of coefficients and confidence intervals for $\log ($ creditpc $) \ldots$. . . 38

Figura 8 - Plots of coefficients and confidence intervals for $\Delta \log ($ credit $)$ for the restricted sample . . . . . . . . . . . . . . . . . 4 45

Figura 10 - Plots of coefficients and confidence intervals for $\Delta \log ($ creditpc $)$ for the restricted sample . . . . . . . . . . . . . . . . . . . . . . 45

Figura 12 - Brazilian Municipalities by number of private and public bank branches - $1990 \ldots \ldots \ldots \ldots \ldots \ldots$

Figura 13 - Brazilian Municipalities by number of private and public bank branches

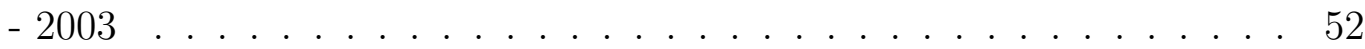

Figura 14 - Brazilian Municipalities by number of private and public bank branches $-2011$

Figura 15 - Plots of coefficients and confidence intervals for $\Delta \log ($ credit $)$ for the 1,097 markets sample . . . . . . . . . . . . . . . . . . .

Figura 17 - Plots of coefficients and confidence intervals for $\Delta \log ($ creditpc $)$ for the 1,097 markets sample . . . . . . . . . . . . . . . . . . . . 54 



\section{Lista de tabelas}

Tabela 1 - Credit cards, debit cards and ATMs in Brazil - 1999 to 2011 . . . . . . 26

Tabela 2 - Descriptive Statistics by number of private bank branches - 2004 to 201132

Tabela 3 - Ordered Probit Results - 2004 to 2011 . . . . . . . . . . . . . 36

Tabela 4 - Multinomial Logit results . . . . . . . . . . . . . . 43 



\section{Introduction}

Financial deepening is a subject that has been widely studied in development economics, through a myriad of perspectives. Access to financial services is strongly correlated to development and there are a number of studies that find that it accelerates growth. (Levine (1999) and Calderón and Liu (2003)). Access to credit, in particular, affects consumption, investments and technologies employed in production, which in turn may alter output of small businesses and farmers (Ghosh, Mookherjee and Ray (2001)). That is, it can be said that credit has many potential benefits to developing communities. For example, it is important to facilitate ${ }^{1}$ :

1. Consumption smoothing and risk sharing: income tends to be more volatile in comparison to consumption, specially in poorer societies, where farmers do not have insurance and adverse weather conditions or plagues can damage output. Credit allows families to maintain their pattern of consumption even if there are unexpected income valleys. In these situations, credit works as a substitute for insurance, which is many times unavailable.$^{2}$

2. Investments and financing of working capital: very low income can prevent savings, which in turn prevents individuals from allocating more resources on their businesses. When investment in fixed capital is needed this becomes more evident, because it usually entails larger sums, which depend on credit to be feasible in the short term.

3. Adoption of new technologies: credit can lower hesitation of using riskier technology that could yield higher returns.

Those are some of the reasons why credit rationing is seen as a grave hurdle to be overcome on the road towards development. Credit rationing occurs when individuals are not able to borrow or when they are not able to borrow the amount they initially intended to or needed. In respect to the former, the focus of research has lied mostly on how poor economies use improvised institutions as substitutes for banks, e.g. microcredit, loans/transfers among families, ROSCAS etc. (Banerjee and Duflo (2011) and Besley, Coate and Loury (2001)). Many studies have showed that those solutions have a positive effect on peoples' lives. However, recently, the magnitude of these impacts have been questioned. Researchers have found that microcredit is not miraculous. It has little to no impact on health, women empowerment and other relevant variables (Banerjee et al. (2014)).

From the intensive margin point of view, even if people have access to financial services, the interest rate level or the type of product offered may constrain credit, reducing the potential positive effects of financial development on economic growth.

1 See Ghosh, Mookherjee and Ray (2001).

2 See Besley (1995) and Ghosh, Mookherjee and Ray (2001) for more on the subject. 
The theoretical literature points to the existence of a number of financial market frictions, which lead to this suboptimal credit provision, especially regarding developing economies. Banerjee and Newman (1993) explore the issue of limited commitment, Aghion and Bolton (1997) analyze moral hazard (hidden action) consequences, Stiglitz and Weiss (1981) model the presence of adverse selection (hidden information).

Credit rationing has been also explored empirically in papers, which examine the relationship between development and financial markets, focusing on identifying the nature of the credit market frictions and its consequences. For instance, Visaria (2009) and Costa and De Mello (2008) seek to measure the importance of enforcement of contracts in India and Brazil, respectively. Paulson, Townsend and Karaivanov (2006) explore the informational problems related to credit in the case of Thailand and Karlan and Zinman (2009) attempt to determine the relative importance of informational problems on loans in South Africa.

Another important, however less explored issue related to credit and growth is the impact of financial infrastructure in the amount of credit. One study by Pande and Burgess (2005), for example, shows that banking rural areas with no prior access to financial institutions reduces poverty. Additionally to physical presence, the introduction of innovations is also a relevant subject on the relationship between credit and development - the financial sector invests largely in technology. On this matter, Jack and Suri (2011) show how the introduction of mobile payment in Kenya increased security and facilitated risk sharing between agents.

Even though innovation has been slightly sidelined by the literature in general, it has been part of Brazilian research due to a number of recent changes in the financial sector. A few examples are the market entry and rapid proliferation of banking correspondents ${ }^{3}$, the internet banking surge and the the Central Bank's discussion on drafting regulation for mobile payment.

Still, research in Brazil has focused less on credit and more on the impact on competition between firms and access to institutions. Using municipality level data, Assunção (2013) evaluates the entry costs of bank branches versus banking correspondents, focusing on how it alters the cost of firm entry in new markets over the years, influencing financial service provision.

3 "Banking correspondents are companies hired by financial institutions and other institutions authorized by the Brazilian Central Bank for the provision of services to customers and users of these institutions. Among the best-known correspondents are the lottery and the postal bank." Correspondents may perform various transactions such as getting and forwarding proposals for opening checking accounts, receiving and making payments and wire transfers; receiving and forwarding proposals relating to loans, among others.(definition taken from BCB's website, available at: <http://www.bcb.gov.br/?CORRESPONDENTESFAQ>). Date of Access: August 24 2015. 
Analyzing the specific case of bank branches, Coelho, De Mello and Rezende (2013) look at the interaction between public and private banks in small municipalities in 2000. The authors use an adaptation of the firm entry model proposed by Bresnahan and Reiss $(1991)^{4}$ to estimate the competitive impact of public banks and conclude that public banks do not compete with private ones. The lack of competition is verified by the fact that private banks' profits are not altered by the entry of public players.

With a similar goal, Sanches, Silva-Junior and Srisuma (2015) use a dynamic entry model with data from isolated municipalities in the period between 1998 and 2010 to reach the conclusion that public banks are complementary to private ones. The presence of public players in a market makes entry more attractive to other banks, that is, they cause positive spillovers that benefit the private banks.

One could argue that with the innovations mentioned before, branches are becoming obsolete and that there is no need to understand how they affect growth. An evidence in that direction is raised by Petersen and Rajan (2002).

They examine data from the United States and find that the distance between small firms and lenders has decreased in the period from 1973 to 1993. They conduct several tests to check for changes in types of lenders, selection bias due to the relationship between borrowers and lenders, consolidating in the banking industry etc. The reason for the shrinking distance seems to be increased lender productivity. Advances in information technology enables more efficient communication in a timely manner, which, in turn, reduces the need to be very close to the borrower.

However there is also evidence that branches are not yet obsolete and can still have an effect on access to financial services. According to Freixas and Rochet (2008), even in developed markets such as the United States, the distance between borrowers and lenders is relatively small - in the US mean distance betweens small firms and bank branches is $6.4 \mathrm{~km}$ and for Belgium this distance is of $2.25 \mathrm{~km}$, indicating that physical proximity matters.

This paper aims to contribute to the literature of financial infrastructure through the analysis of bank branches' impact on local credit markets in Brazil. Is it true that physical infrastructure still matters? Should incentive to increase the number and capillarity of branches be considered as an alternative for public policy? Or are bank branches an outdated mean of financial service provision?

$\overline{4}$ Section 3.1 discuss this model in further detail. 
Since a bank's decision to enter a market is influenced by variables that also affect credit demand, our estimation is cursed with endogeneity. To deal with this issue, we employ a two-stage estimation strategy. In the first stage we use an Industrial Organization firm entry model, proposed by Bresnahan and Reiss (1991) to estimate the number of firms in a given market. The model considers homogeneous agents and uses a profit function to determine thresholds for firm entry, as will be detailed in section 3.1. It is estimated through an ordered Probit.

In the second stage we use the predicted number of firms, eliminating the common factor between the number of firms and our dependent variable, which is equilibrium credit amount. We then estimate the relation between the predicted number of bank branches and credit. As an additional exercise we present a second IO model, which is less restrictive and considers more than one type of agent, as will be explored bellow. To the best of our knowledge, this is the first time that an entry IO model is used as a first stage estimation in an attempt to avoid endogeneity.

This paper consists of five more sections in addition to this introduction. In section 2 we introduce the financial sector in Brazil and how the provision of financial services has evolved over the years. Section 3 presents the data to be used on our estimation and the empirical strategy we chose, that is, the IO models used and the second stage strategy. Section 4 presents the results, section 5 describes the additional exercise. Finally, section 6 delivers our concluding remarks. 


\section{Banking sector and financial deepening in Brazil}

Brazil's financial sector has evolved considerably over the last 25 years. During the early 90's, almost half of municipalities had no bank branch and internet was virtually nonexistent. Back then, ATMs were a novelty, credit cards were not as common and many innovations such as the aforementioned correspondents had not been introduced. Figure 1 shows the evolution of bank branches from 1990 to 2014.

Brazil suffered from very high inflation from 1987 to 1994, when the hyperinflation finally subsided due to the Real Plan, which introduced a new currency, the Real. During the period of high inflation, banks profited from the inflation float, that is, the spread resulting from investments in government securities with money raised on deposits that earned lower rates. After stabilization the profit from deposits dwindled and banks reduced the number of branches that had become to costly to maintain. This movement is noticeable in the slight fall of total branches right after 1994. (De Mello and Garcia (2012))

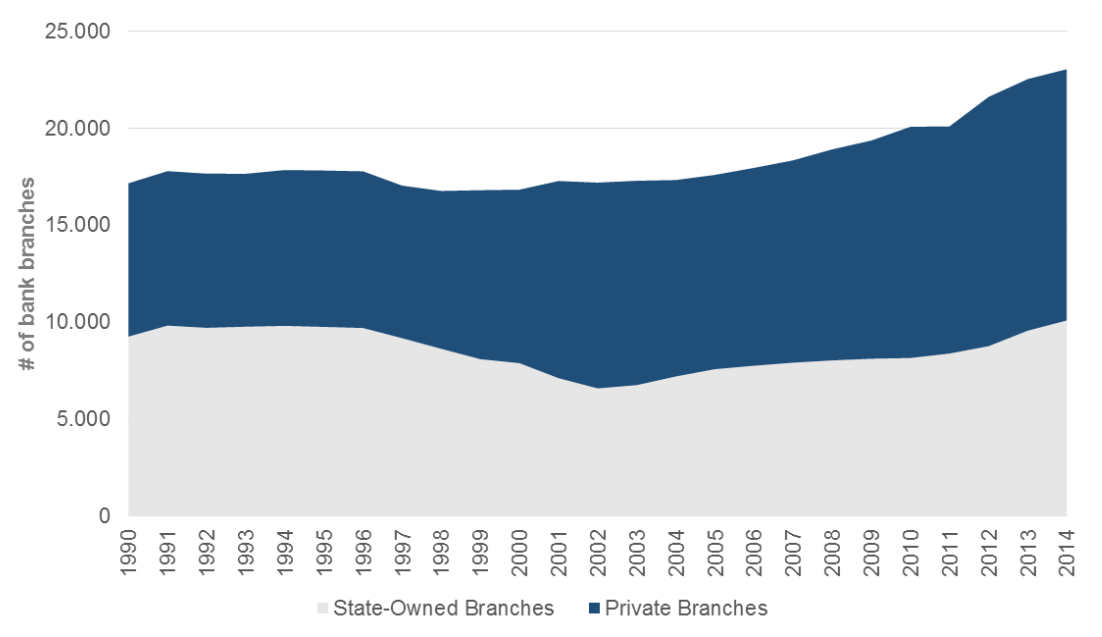

Figure 1 - State-Owned and Private bank Branches in Brazil - 1990 to 2015 Source: Brazilian Central Bank (BCB). Prepared by the authors.

Close to the end of the decade, many banks owned by state-level government became heavily indebted. The federal government then created a program to sell those banks to the private initiative: PROES (Program of incentives to reduce the State presence in Banking Activities). Many banks were sold, reducing the quantity of public banks in the market and, therefore, the quantity of state-owned bank branches, as can be perceived in Figure 1. Until 1997, state-owned branches represented close to $55 \%$ of total branches ${ }^{1}$. After 1999, the number of private branches surpassed state-owned ones, reaching $56 \%$ of

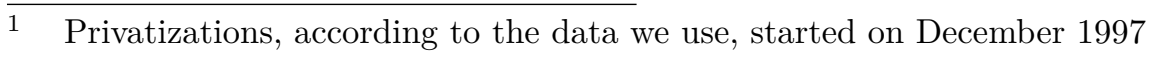


branches in 2014. However, Banco do Brasil and Caixa Econômica Federal - both managed by the federal government - went on having a strong presence in all of Brazil.

Taking into consideration that Brazil has continental dimensions, the dispersion of bank branches throughout the country is as important to measure the development of the financial system as the total amount of branches. To illustrate how bank branches are spread across Brazil, Figure 2 below presents three maps representing Brazilian municipalities. Each of them shows the situation of bank branches by municipality in a year. In the early 90's, 2,723 municipalities had no bank branch and only 445 cities had five or more branches. 2003 and 2011, which represent the year right before the starting point and end of our credit data sample, show a much more positive image, the maps are noticeably darker due to the spread of banking. 2003 has $16 \%$ less municipalities with zero offices when compared to 1990 and 2011 has 1,982 municipalities with zero branches, 14\% less than in the year of 2003. The number of markets with 5 or more firms also rose substantially from 445 in 1990 to 720 in 2011.
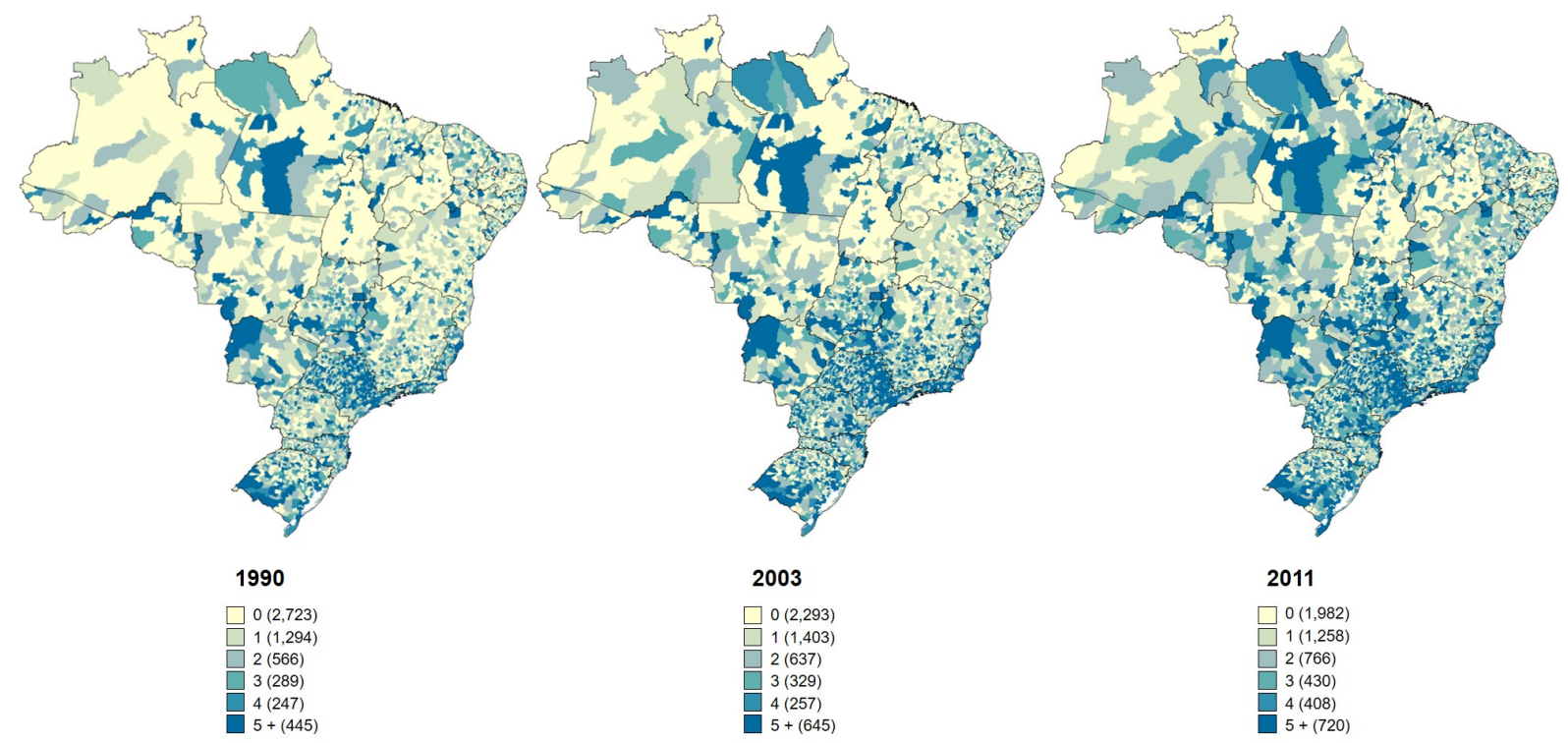

Figure 2 - Brazilian Municipalities by number of bank branches - 1990, 2003 and 2011

Note: data from Brazilian Central Bank (BCB) and shapefiles from The Brazilian Institute of Geography and Statistics (IBGE). Prepared by the authors.

The comparison of these maps to the distribution of GDP per capita in Brazil (as seen on Figure 3 below) raises interesting conclusions: the concentration of lower GDP per capita values in the north and northeast of Brazil is much more evident than the lack of banks in this region. That is, even with the spread of banking, GDP per capita does not increase accordingly. 
The provision of financial services in those areas is less obvious, in the sense that banks have lower incentives to open offices in markets which are not that prosperous. Even so, there are bank branches, mainly due to the presence of state owned banks. Since these are owned by the government, they tend to have social-economic objectives linked to development goals and are not only profit seekers. See Appendix A for maps differing public from private banks.

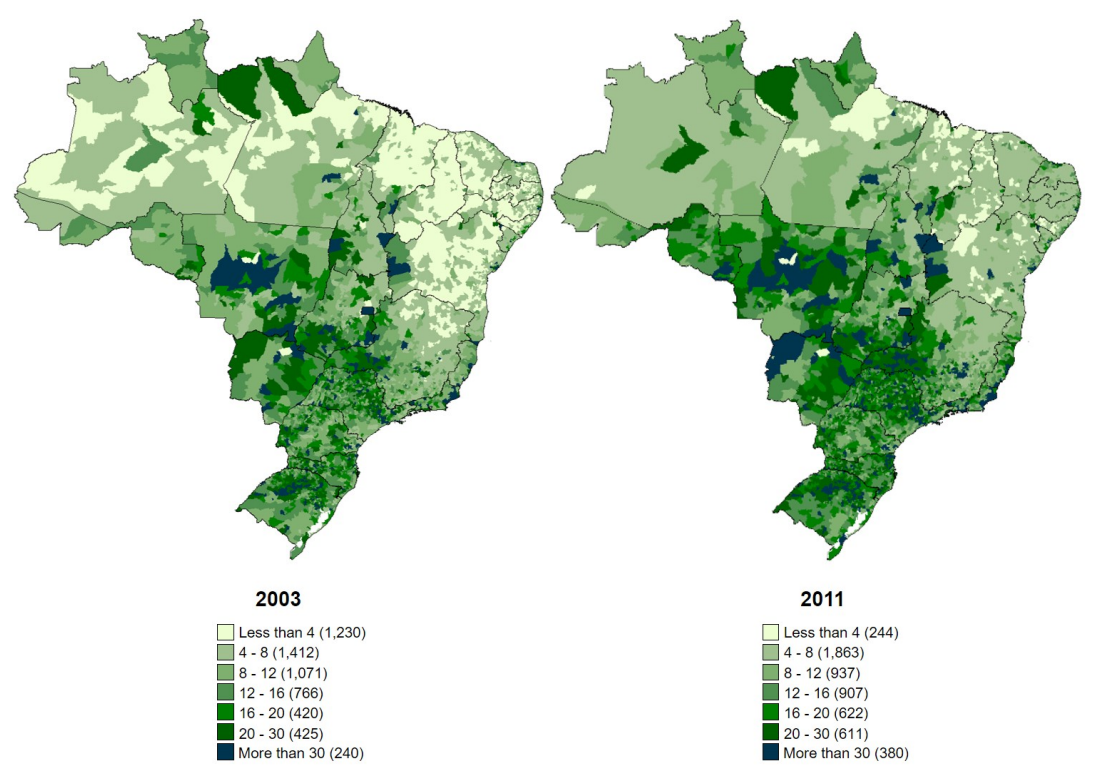

\section{Figure 3 - Brazilian Municipalities by GDP per capita in BRL thousands - 2003 and 2011}

Note: data and shapefiles from The Brazilian Institute of Geography and Statistics (IBGE). Prepared by the authors.

Aside from the increase in banking dispersion, in the last three decades we have seen a lot of changes in the Brazilian financial sector, the introduction of new means of customer service such as internet and mobile banking.

Internet banking has greatly decreased costs involved with financial services, considering it allows individuals to make payments, take credit and check their bank statements without leaving home. In Brazil, the increase of services available caused a greater number of transactions on-line: in $201035 \%$ of transactions (or 10.2 billion) were made through internet banking, in 2014, 50\% of transactions (or 23.5 billion) were originated on internet or mobile banking, a growth growth of $132 \%^{2}$.

In addition to on-line banking, Brazil has also presented growth in financial access due to bank correspondents - authorized stores, lotteries and others institutions that may be non-financial, which can provide financial services through contracts with banks. This 
institution, created in 1999, significantly reduced costs of financial deepening. This was a very important advancement, especially because it has helped the implementation of Programa Bolsa Família (PBF), a conditional cash transfer program designed by the government to reduce extreme poverty and increase access to education. It depends on its beneficiaries having access to Caixa Econômica Federal (CEF), a state owned bank, responsible for the distribution of transfers. To facilitate access, CEF increased its reach and presence in Brazil through correspondents.

Furthermore, greater presence of banks in municipalities has also reflected in more ATMs and options for currency as means of payment such as debit and credit cards. In Table 1 bellow, we present the evolution of ATMs and cards between 1999 and 2011. During these 9 years, ATMs more than doubled, debit cards more than tripled and credit cards increased its presence from 23 million to 169 million in 2011, a 622\% growth rate.

Table 1 - Credit cards, debit cards and ATMs in Brazil - 1999 to 2011

\begin{tabular}{lccccccccccccc}
\hline & 1999 & 2000 & 2001 & 2002 & 2003 & 2004 & 2005 & 2006 & 2007 & 2008 & 2009 & 2010 & 2011 \\
\hline $\begin{array}{l}\text { \# of ATMs } \\
\text { (in thousands) }\end{array}$ & 86 & 98 & 111 & 130 & 136 & 139 & 147 & 148 & 153 & 158 & 166 & 175 & 174 \\
$\begin{array}{l}\text { Cards in circulation with } \\
\text { credit function (in millions) }\end{array}$ & 23 & 29 & 35 & 41 & 44 & 53 & 68 & 85 & 118 & 138 & 152 & 172 & 169 \\
$\begin{array}{l}\text { Cards in circulation with } \\
\text { debit function (in millions) }\end{array}$ & 67 & 85 & 101 & 114 & 125 & 149 & 164 & 174 & 182 & 208 & 221 & 226 & 258 \\
\hline
\end{tabular}

Source: Banks and Tecban. Data published by the Department of Banking Operations and Payment Systems (DEBAN) of Brazilian Central Bank: Diagnosis of Brazil's Retail Payment System - Statistical Addendum for 2005, 2010 and 2011. Prepared by the authors.

The increase in access to financial institutions reflects in the growing loan amount in Brazil. Figure 4 illustrates the evolution of both the amount of credit in Brazil and the credit/GDP ratio between 2004 and 2011. Both figures increased considerably during this period. Credit as a percentage of GDP rose from 19\% in 2004 to $46 \%$ in 2011 and the loan amount more than tripled from BRL 599 billion to BRL 1,910 billion.

Could it be possible to measure how much of this growth in financial deepening happened due to bank branches presence? There are many market characteristics that influence both branch opening and equilibrium credit. To attempt to reduce the bias introduced by these non-observable variables, we will model the decision of entry in markets by private and public banks. 


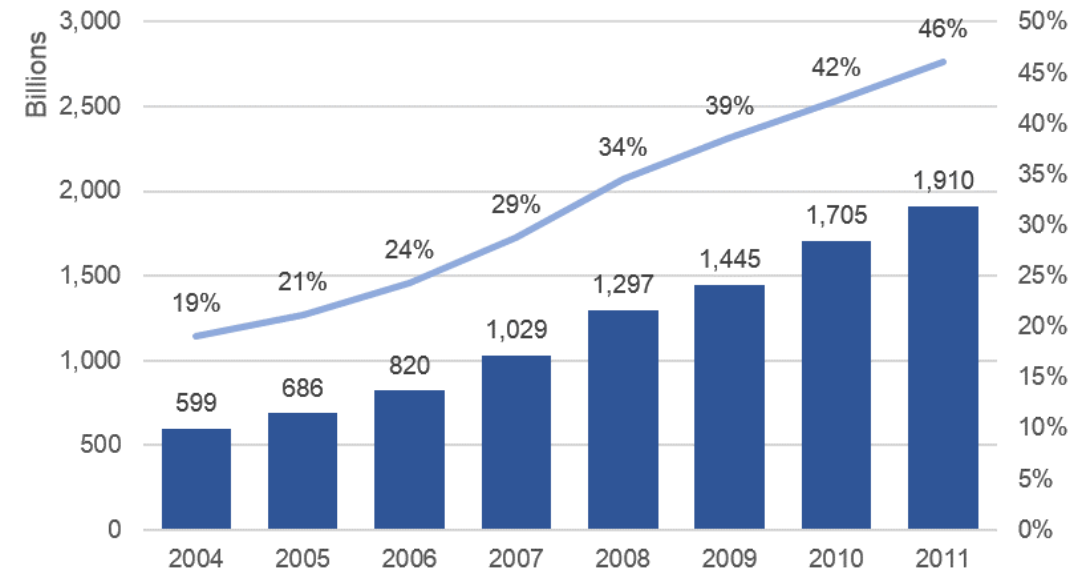

Figure 4 - Sample total credit volume and credit as \% of GDP -2004 to 2011

Source: Brazilian Central Bank (BCB) and The Brazilian Institute of Geography and Statistics (IBGE). Note: Sample consists of all loan contracts over BRL 5,000 of residents/firms from brazilian municipalities. Prepared by the authors. GDP considered was total GDP of all municipalities. 



\section{Empirical strategy and data}

\subsection{Modeling firm entry and credit market equilibrium under com- plete information and homogeneity}

Our interest lies in determining how bank branches influences local credit markets. With that in mind, we first explain how these variables are related and what could be the possible sources of issues in estimating such relation. We will estimate the equilibrium amount of credit in a market as a function of market characteristics, the number of bank branches and an error term:

$$
C_{i t}=f\left(\mathbf{x}_{i t}, N_{i t} ; \beta, \rho\right)+\epsilon_{j t}
$$

In which $\mathbf{x}_{i t}$ represents the vector of markets' characteristics such as population, GDP per capita, elderly proportion in total population etc. $\beta$ and $\rho$ are parameters. $N_{i t}$ is the number of branches active in the municipality in year $t$, which is also a function of market characteristics $\left(\mathbf{x}_{i t}\right)$. Additionally, it is a function of the fixed cost of opening a branch $(F)$ :

$$
N_{i t}=g\left(\mathbf{x}_{i t}, F ; \theta\right)+u_{i t}
$$

The problem with estimating both of these equations is that, as discussed in the introduction, there are probably omitted variables that drive the credit demand, which affect both the number of branches and the credit market. Expected growth is an example; higher expected growth probably generate higher credit demand and more bank branches. It affects both variables, but in different ways. The fixed cost of opening a bank branch is important in that sense because it creates jumps in the probability of having a branch: for example, the population rises until the point where the expected revenue surpasses the fixed cost and it is worth to open a branch, but credit demand does not vary so abruptly, nor does the market equilibrium.

In any case, even if the variables are affected in different ways, $N_{i t}$ variable is correlated with the credit equation's error term, since probably part of $u_{i t}$ is present in $\epsilon_{i t}$ as well, leading to endogeneity. To eliminate the correlation with the error term we propose modeling firm entry and using the expected value of $N_{i t}$ as the explanatory variable. This 
way, we would eliminate $u_{i t}$. What would be left is the exogenous part of $N_{i t}$, which is not correlated to $\epsilon_{i t}$. Thus, the specification of the market credit equation would be:

$$
C_{i t}=\beta \mathbf{x}_{i t}+\rho \hat{N}_{i t}+\epsilon_{i t}
$$

To model firm entry we apply two IO models: (1) the model presented in Bresnahan and Reiss (1991); and (2) in an additional exercise, we use a reduced-form version of the model used by Sanches, Silva-Junior and Srisuma (2015). To the best of our knowledge this is the first time an IO entry model is used as a first stage to mitigate endogeneity. Since we were not able to find exogenous variations in this market, we used this second-best solution to evaluate how branches affect credit.

In their paper published in 1991, Bresnahan and Reiss develop an empirical model to predict firm entry and its impact on competition in concentrated markets in which pricecost margins are not observed by the econometrician. The model is based on the idea that firm profit is non-increasing on the number of players, i.e. monopoly profit is the greatest, followed by the duopoly profit that is less or equal to the previous one and so forth.

Based on this hypothesis, the authors design an ordered Probit, which can be used to estimate the population entry thresholds of firms in a given sector, that is, what is the necessary market size so that the firms may have at least zero profit. Note that all firms have the same profit because the methodology assumes product and firm homogeneity. The authors propose that profit for $N$ firms has the following specification:

$$
\Pi_{N}=S(\mathbf{Y} ; \lambda) V_{N}(\mathbf{X} ; \alpha, \beta)-F_{N}(\mathbf{W} ; \gamma)+\epsilon
$$

Where $S$ represents market size (municipality population and growth expectancy) ${ }^{1}, F_{N}$ is the fixed cost and $V_{N}$ is the variable per capita profit, both are considered to be linear and vary according to the number of firms:

$$
V_{N}=\alpha_{1}+\mathbf{X} \beta-\sum_{n=2}^{N} \alpha_{n}
$$

$1 \quad$ Population growth expectancy is represented by the negative and positive growth rate from the five previous years. Bresnahan and Reiss (1991) also use commuters from nearby towns to estimate $S$. We chose not to use this variable because it is only available for census years. 


$$
F_{n}=\gamma_{1}+\gamma_{L} W_{L}+\sum_{n=2}^{N} \gamma_{n}
$$

Where $X$ is a vector of market characteristics and $\alpha_{n}$ and $\gamma_{N}$ are constants greater than or equal to zero, which represent the effect of the $n^{\text {th }}$ firm on profit, i.e. the larger the number of firms in the market, the lower their individual profit. Finally, $W_{L}$ is the land value to differentiate fixed costs between markets.

After estimating their model, the authors use the zero profit condition to calculate the market size required for a new firm to entry the market. This methodology, however interesting, is not the best fitted for use in the second stage proposed here. Since the prediction by thresholds is discrete, we opted for using the probability of branch existence. The result of the ordered Probit proposed allows for the calculation of the probability of having private bank branches (i.e. $1-\widehat{P(N=0)})$.

\subsection{Data}

The data used in this paper includes sociodemographic variables reported by IBGE, National Treasury Secretariat (Ministry of Finance), Ministry of Labor and Employment and DATASUS (IT Department of the Public Health System - Ministry of Health), in addition to information on bank branches provided by the Central Bank of Brazil ${ }^{2}$ and information on credit contracts from BRL 5,000 or more from the Credit Information System (SCR), also from the Central Bank ${ }^{3}$.

In Table 2 we present some of the variables used and their average, categorized by the number of private bank branches in the municipality. ${ }^{4}$ Our sample does not consist of all municipalities in Brazil, Bresnahan and Reiss propose a selection of markets that are isolated to avoid contamination among relevant geographic markets. We follow criteria

2 The number of bank branches in each municipality is available on the central bank's website. However, as we needed data on the owner of each branch, we requested this information under the Access to Information Act (in Portuguese, Lei de Acesso à Informação - LAI).

3 Provided by the Brazilian Central Bank also under the Access to Information Act.

4 Due to PROES, there are some banks, which were owned by the states in the beginning of the sample and soon after were bought by the private sector. There are even banks that had been acquired already, but for some reason are still listed by their old name. Since the acquiring banks paid a price for the acquired branches, we considered that the acquired bank closes the branch and the buyer opens a branch in the market. Examples of these changes in ownership are: Banco Banestado that was a state owned bank from the state of Paraná, it was privatized in 2000, when it was acquired by Itaú. BANDEPE bank (Banco do Estado de Pernambuco) was acquired by ABN AMRO in 1998 . BANESPA (Banco do Estado de São Paulo) was bought by Santander in 2000. BEC (Banco do Estado do Ceará) was privatized in 2005, when it was acquired by Bradesco. BEG (banco do Estado de Goiás) was privatized in 2001. Nossa Caixa was acquired by Bank of Brazil (BB) in 2009. 
proposed by Bresnahan and Reiss (1991) and Sanches, Silva-Junior and Srisuma (2015), selecting municipalities that are at least $20 \mathrm{~km}$ away from other municipalities and $100 \mathrm{~km}$ away from state capitals. We also drop from our sample state capitals, metropolitan areas ${ }^{5}$ and municipalities, which have had more than 10 bank branches in a given year since 1900 or ones, which have missing information for entry/exit dates of branches. Due to the restrictions, our sample consists of 1,097 isolated markets (municipalities) in Brazil over 8 years (2004 to 2011).

Table 2 - Descriptive Statistics by number of private bank branches -2004 to 2011

\begin{tabular}{|c|c|c|c|c|c|c|c|c|c|c|}
\hline $\begin{array}{l}\text { \# private } \\
\text { branches }\end{array}$ & $\mathbf{N}$ & $\begin{array}{r}\text { Population } \\
\text { (in millions) }\end{array}$ & $\begin{array}{c}\text { Elderly } \\
(\%)\end{array}$ & $\begin{array}{c}\text { Positive Pop } \\
\text { Growth (\%) }\end{array}$ & $\begin{array}{c}\text { Negative Pop } \\
\text { Growth (\%) }\end{array}$ & $\begin{array}{c}\text { GDP Per } \\
\text { Capita (BRL thou) }\end{array}$ & $\begin{array}{l}\text { \# public } \\
\text { branches }\end{array}$ & $\begin{array}{c}\text { Land Value } \\
\text { (BRL/ha) }\end{array}$ & $\begin{array}{c}\text { Credit } \\
\text { (BRL million) }\end{array}$ & $\begin{array}{c}\text { Credit Per } \\
\text { Capita (BRL thou) }\end{array}$ \\
\hline 0 & 5,740 & 13.4 & 9.1 & 11.3 & -3.0 & 10.1 & 0.5 & 1.5 & 18.5 & 2.3 \\
\hline 1 & 2,164 & 24.9 & 9.5 & 8.9 & -2.8 & 12.8 & 1.0 & 2.4 & 60.0 & 3.1 \\
\hline 2 & 559 & 33.0 & 9.1 & 9.8 & -1.3 & 17.0 & 1.7 & 3.4 & 193.7 & 6.2 \\
\hline 3 & 192 & 45.3 & 9.9 & 9.4 & -1.1 & 19.1 & 2.2 & 3.9 & 285.7 & 7.0 \\
\hline 4 & 85 & 61.0 & 9.9 & 9.9 & -1.0 & 19.4 & 2.5 & 4.6 & 671.1 & 12.6 \\
\hline 5 & 24 & 80.2 & 8.8 & 15.8 & -1.1 & 21.6 & 2.3 & 3.7 & 666.6 & 9.2 \\
\hline 6 & 3 & 95.1 & 11.4 & 77.9 & -3.9 & 53.2 & 2.3 & 4.5 & 873.7 & 9.3 \\
\hline 7 & 7 & 144.0 & 7.2 & 41.3 & 0.0 & 43.6 & 2.4 & 3.3 & 412.2 & 0.0 \\
\hline 8 & 2 & 171.4 & 8.3 & 20.5 & 0.0 & 63.2 & 2.0 & 3.0 & 820.0 & 4.8 \\
\hline Total & 8,776 & 19.0 & 9.2 & 10.6 & -2.8 & 11.6 & 0.7 & 1.9 & 54.6 & 2.9 \\
\hline
\end{tabular}

Most of the sample consists of municipalities with zero $(5,740)$ or just one private bank branch $(2,164)$. As expected, population, GDP per capita and amount of credit are increasing in number of branches. The land value also rises as the number of branches grows. This is probably due to the fact that municipalities with more valuable land are more developed and therefore, have more branches on average. The percentage of elderly is decreasing, since municipalities with the highest proportion of elderly are, on average, less productive (fewer workers).

Since the model proposed by Bresnahan and Reiss relies a great deal on population to predict the number of firms in a market, it would be interesting to verify if our sample indicates that these variables are related. In Figure 5 bellow, we plot the Kernel density of population for each quantity of firms, considering our sample of isolated municipalities. The chart shows that municipalities with one bank branch have population concentrated nearer to zero than to 50 thousand people, as the number of firms increases, the population density is dislocated to the right and becomes more disperse.

The progressive spreading out of the densities may indicate that the relation between population and bank branches becomes fainter in larger municipalities, which may have 2 , 3 or even more branches.

$5 \quad$ As defined by The Brazilian Institute of Geography and Statistics (IBGE) 


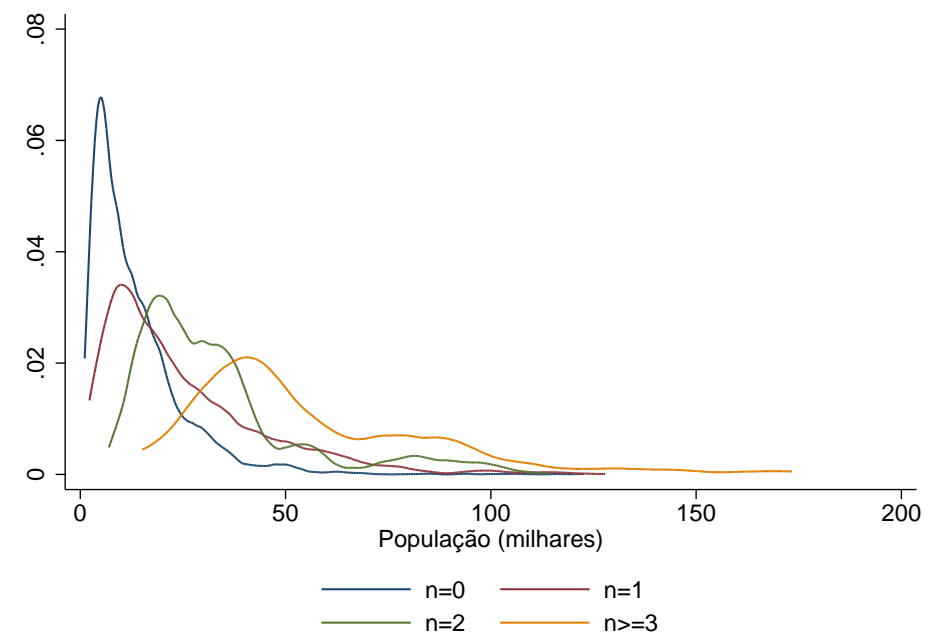

Figure 5 - Kernel density of population (thousands) conditional to the number of bank branches in each municipality - pooled data 2004 to 2011

Note: data from Brazilian Central Bank (BCB) and The Brazilian Institute of Geography and Statistics (IBGE). 



\section{Results}

\subsection{First stage: Entry under complete information}

Firstly we model firm entry using the model proposed by Bresnahan and Reiss (1991) detailed above. As discussed, the framework designed by the authors considers homogeneous firms and complete information. We consider public banks to be exogenous, since we believe that they are intrinsically different from private banks, which is consistent with recent literature that points to state-owned banks having different goals from private sector such as social-development objectives and are also subject to lower efficiency levels and political interests (Sanches, Silva-Junior and Srisuma (2015) LA PORTA, LOPEZ-DE-SILANES and Shleifer (2002), Coelho, De Mello and Rezende (2013)). Table 3 presents the results for the cross section estimations of the model from 2004 to 2011.

Estimates consider only the entry thresholds by three firms because we need enough markets with each number of branches to obtain consistent estimates for the parameters. We selected three firms as the last threshold using the criteria determined by Bresnahan and Reiss (1991), that is, the existence of at least 10 municipalities in each category.

For all of the years, except 2007 and 2008, at least one of the $\alpha_{N}$ had to be constrained to zero, in such cases, variable profit is considered to be the same for $N-1$ and $N$ firms. GDP per capita appears to have a positive and significant (at a $5 \%$ level) effect on entry. The result of the Bresnahan and Reiss exercise shows that public bank branches compete with private ones, generating a negative impact on entry. Land value also attracts players ( $F$ is subtracted from profit, that is, if the estimated coefficient is less than zero, $F$ actually increases profit in our estimated model), probably because costlier places are usually more developed and hence, allow for higher revenues.

The percentage of elderly people also appears to affect entry in a positive way, which could be due to the fact that older people make more use of the physical infrastructure of banks - they are less familiar with innovations and have to retrieve their government payed pensions.

We then use the resulting probabilities to estimate the probability of having one or more branch in a market. As has been stated, our sample consists of small isolated markets, therefore, we expected that the effect of having at least one branch versus having zero branches would be easier to detect than the effect of the number of branches.

As discussed before, the result of the ordered Probit proposed allows for the estimation 
Table 3 - Ordered Probit Results - 2004 to 2011

\begin{tabular}{|c|c|c|c|c|c|c|c|c|}
\hline \multicolumn{9}{|c|}{ Dependent Variable: PVbranches } \\
\hline & (1) & $(2)$ & $(3)$ & $(4)$ & $(5)$ & (6) & (7) & (8) \\
\hline & 2004 & 2005 & 2006 & 2007 & 2008 & 2009 & 2010 & 2011 \\
\hline \multicolumn{9}{|l|}{ Lambda } \\
\hline Pgrowth & $\begin{array}{c}-0.006^{* * *} \\
(0.002)\end{array}$ & $\begin{array}{c}-0.005^{* * *} \\
(0.002)\end{array}$ & $\begin{array}{c}-0.028^{* * *} \\
(0.006)\end{array}$ & $\begin{array}{c}-0.017^{* * *} \\
(0.004)\end{array}$ & $\begin{array}{c}-0.020^{* * *} \\
(0.004)\end{array}$ & $\begin{array}{c}-0.018^{* * *} \\
(0.003)\end{array}$ & $\begin{array}{c}-0.016^{* * *} \\
(0.003)\end{array}$ & $\begin{array}{c}-0.012^{* * *} \\
(0.004)\end{array}$ \\
\hline Ngrowth & $\begin{array}{l}-0.010 \\
(0.009)\end{array}$ & $\begin{array}{l}-0.012 \\
(0.009)\end{array}$ & $\begin{array}{l}-0.001 \\
(0.012)\end{array}$ & $\begin{array}{c}0.001 \\
(0.012)\end{array}$ & $\begin{array}{c}0.004 \\
(0.013)\end{array}$ & $\begin{array}{c}0.007 \\
(0.010)\end{array}$ & $\begin{array}{c}0.010 \\
(0.009)\end{array}$ & $\begin{array}{c}0.005 \\
(0.009)\end{array}$ \\
\hline \multicolumn{9}{|l|}{ Beta } \\
\hline GDPpc & $\begin{array}{c}1.969^{* * *} \\
(0.210)\end{array}$ & $\begin{array}{c}2.186^{* * *} \\
(0.221)\end{array}$ & $\begin{array}{c}2.275 * * * \\
(0.253)\end{array}$ & $\begin{array}{c}2.013^{* * *} \\
(0.218)\end{array}$ & $\begin{array}{c}1.975^{* * *} \\
(0.219)\end{array}$ & $\begin{array}{c}2.761^{* * *} \\
(0.256)\end{array}$ & $\begin{array}{c}2.319^{* * *} \\
(0.229)\end{array}$ & $\begin{array}{c}1.338^{* * *} \\
(0.165)\end{array}$ \\
\hline PBbranches & $\begin{array}{c}-4.784^{* * *} \\
(1.515)\end{array}$ & $\begin{array}{c}-6.091^{* * *} \\
(1.551)\end{array}$ & $\begin{array}{c}-6.909 * * * \\
(1.685)\end{array}$ & $\begin{array}{c}-7.694^{* * *} \\
(1.689)\end{array}$ & $\begin{array}{c}-6.883^{* * *} \\
(1.620)\end{array}$ & $\begin{array}{c}-6.688^{* * *} \\
(1.614)\end{array}$ & $\begin{array}{c}-5.814^{* * *} \\
(1.620)\end{array}$ & $\begin{array}{c}-4.902^{* * *} \\
(1.595)\end{array}$ \\
\hline Elderly & $\begin{array}{c}210.887^{* * *} \\
(63.382)\end{array}$ & $\begin{array}{c}207.097^{* * *} \\
(62.179)\end{array}$ & $\begin{array}{c}181.963^{* * *} \\
(63.947)\end{array}$ & $\begin{array}{c}250.964^{* * *} \\
(53.924)\end{array}$ & $\begin{array}{c}239.028^{* * *} \\
(51.576)\end{array}$ & $\begin{array}{c}215.681^{* * *} \\
(50.757)\end{array}$ & $\begin{array}{c}186.313^{* * *} \\
(50.506)\end{array}$ & $\begin{array}{c}185.088^{* * *} \\
(48.675)\end{array}$ \\
\hline \multicolumn{9}{|l|}{ F } \\
\hline Land Value & $\begin{array}{c}-0.252^{* * *} \\
(0.022)\end{array}$ & $\begin{array}{c}-0.264^{* * *} \\
(0.022)\end{array}$ & $\begin{array}{c}-0.257^{* * *} \\
(0.022)\end{array}$ & $\begin{array}{c}-0.251^{* * *} \\
(0.022)\end{array}$ & $\begin{array}{c}-0.248^{* * *} \\
(0.022)\end{array}$ & $\begin{array}{c}-0.239 * * * \\
(0.022)\end{array}$ & $\begin{array}{c}-0.242^{* * *} \\
(0.022)\end{array}$ & $\begin{array}{c}-0.250^{* * *} \\
(0.022) \\
\end{array}$ \\
\hline$\alpha_{1}$ & $\begin{array}{c}24.104^{* * *} \\
(6.597)\end{array}$ & $\begin{array}{c}25.828^{* * *} \\
(6.646)\end{array}$ & $\begin{array}{c}31.329^{* * *} \\
(7.112)\end{array}$ & $\begin{array}{c}28.056^{* * *} \\
(7.198)\end{array}$ & $\begin{array}{c}24.408^{* * *} \\
(7.087)\end{array}$ & $\begin{array}{c}20.784^{* * *} \\
(6.944)\end{array}$ & $\begin{array}{c}21.668^{* * *} \\
(7.118)\end{array}$ & $\begin{array}{c}26.398^{* * *} \\
(6.870)\end{array}$ \\
\hline$\alpha_{2}$ & $\begin{array}{c}0.000 \\
(.)\end{array}$ & $\begin{array}{c}3.469 \\
(4.000)\end{array}$ & $\begin{array}{c}7.300^{*} \\
(4.140)\end{array}$ & $\begin{array}{c}6.746 \\
(4.209)\end{array}$ & $\begin{array}{c}6.553 \\
(4.066)\end{array}$ & $\begin{array}{c}4.713 \\
(4.010)\end{array}$ & $\begin{array}{c}4.259 \\
(3.965)\end{array}$ & $\begin{array}{c}1.287 \\
(3.634)\end{array}$ \\
\hline$\alpha_{3}$ & $\begin{array}{c}2.541 \\
(4.878)\end{array}$ & $\begin{array}{c}0.000 \\
(.)\end{array}$ & $\begin{array}{c}0.000 \\
(.)\end{array}$ & $\begin{array}{c}0.824 \\
(5.319)\end{array}$ & $\begin{array}{c}0.892 \\
(4.917)\end{array}$ & $\begin{array}{c}0.000 \\
(.)\end{array}$ & $\begin{array}{c}0.000 \\
(.)\end{array}$ & $\begin{array}{c}0.000 \\
(.)\end{array}$ \\
\hline$\gamma_{1}$ & $\begin{array}{c}1.854^{* * *} \\
(0.102)\end{array}$ & $\begin{array}{c}1.952^{* * *} \\
(0.106)\end{array}$ & $\begin{array}{c}1.865^{* * *} \\
(0.107)\end{array}$ & $\begin{array}{c}1.947^{* * *} \\
(0.113)\end{array}$ & $\begin{array}{c}1.884^{* * *} \\
(0.111)\end{array}$ & $\begin{array}{c}1.901^{* * *} \\
(0.113)\end{array}$ & $\begin{array}{c}1.868^{* * *} \\
(0.113)\end{array}$ & $\begin{array}{c}1.865^{* * *} \\
(0.114)\end{array}$ \\
\hline$\gamma_{2}$ & $\begin{array}{c}1.409^{* * *} \\
(0.079)\end{array}$ & $\begin{array}{c}1.349^{* * *} \\
(0.125)\end{array}$ & $\begin{array}{c}1.312^{* * *} \\
(0.122)\end{array}$ & $\begin{array}{c}1.322^{* * *} \\
(0.126)\end{array}$ & $\begin{array}{c}1.318^{* * *} \\
(0.124)\end{array}$ & $\begin{array}{c}1.382^{* * *} \\
(0.127)\end{array}$ & $\begin{array}{c}1.349^{* * *} \\
(0.124)\end{array}$ & $\begin{array}{c}1.316^{* * *} \\
(0.118)\end{array}$ \\
\hline$\gamma_{3}$ & $\begin{array}{c}0.968^{* * *} \\
(0.203)\end{array}$ & $\begin{array}{c}0.988^{* * *} \\
(0.111)\end{array}$ & $\begin{array}{c}0.984^{* * *} \\
(0.111)\end{array}$ & $\begin{array}{c}0.982^{* * *} \\
(0.206)\end{array}$ & $\begin{array}{c}0.929^{* * *} \\
(0.194)\end{array}$ & $\begin{array}{c}1.075^{* * *} \\
(0.118)\end{array}$ & $\begin{array}{c}1.045^{* * *} \\
(0.114)\end{array}$ & $\begin{array}{c}0.910^{* * *} \\
(0.100)\end{array}$ \\
\hline $\mathrm{N}$ & 1,097 & 1,097 & 1,097 & 1,097 & 1,097 & 1,097 & 1,097 & 1,097 \\
\hline log likelihood & -724.016 & -706.099 & -705.526 & -701.164 & -703.045 & -686.989 & -700.428 & -729.372 \\
\hline chi2 & 15.871 & 11.232 & 22.477 & 15.557 & 28.979 & 29.033 & 22.917 & 11.171 \\
\hline $\mathrm{p}$ & 0.000 & 0.004 & 0.000 & 0.000 & 0.000 & 0.000 & 0.000 & 0.004 \\
\hline
\end{tabular}

Note: PGrowth (Ngrowth) represents population growth in the previous 5 years if it was positive (negative). GDPpc is the municipality GDP per capita in BRL of 2011. PBbranches is the number of public bank branches. Elderly is the percentage of people who are at least 60 years old. and Land Value is the value of one hectare of agricultural land in BRL of 2011.

Standard errors in parentheses

$* \mathrm{p}<0.10,{ }^{* *} \mathrm{p}<0.05,{ }^{* * *} \mathrm{p}<0.01$. 
of market thresholds, in addition to the probability we will use in our second stage. The population thresholds for $N$ firms happens when $\Pi_{N}=0$, which means that the market size that allows the entry of $N$ firms is determined by the equation below,derived from the profit equation presented before:

$$
S_{N}=\frac{\hat{\gamma_{1}}+\hat{\gamma_{L}} \bar{W}_{L}+\sum_{n=2}^{N} \hat{\gamma_{n}}}{\hat{\alpha_{1}}+\overline{\mathbf{X}} \hat{\beta}-\sum_{n=2}^{N} \hat{\alpha_{n}}}
$$

To estimate the number of bank branches in each municipality we compare the threshold given by the model to the municipality population. We then plotted the Kernel density just as in Figure 5, but using the predicted number of branches according to the population thresholds calculated with the model.

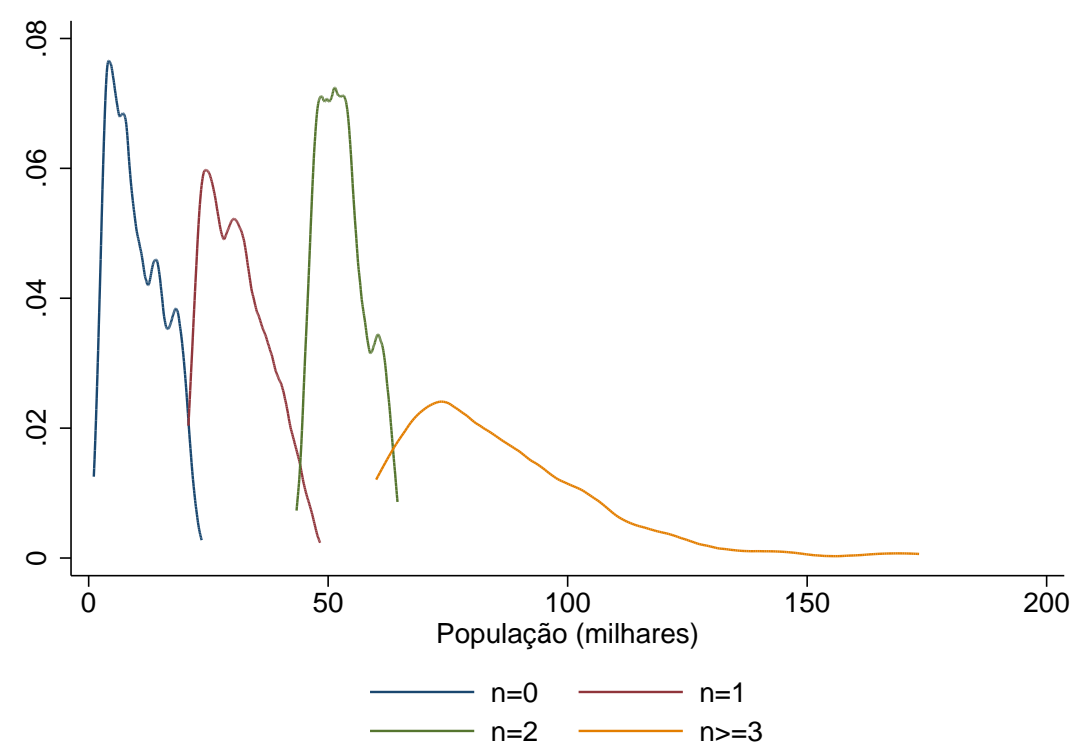

Figure 6 - Kernel density of population (thousands) conditional to the predicted number of bank branches in each municipality according to population thresholds - pooled data - 2004 to 2011

Note: Calculated using estimation results.

As a direct result from calculating bank branches according to population, the densities are more clearly defined in terms of population intervals as seen in the chart. As in Figure 5 , the number of municipalities with more than or three branches is lower than with less banks. 


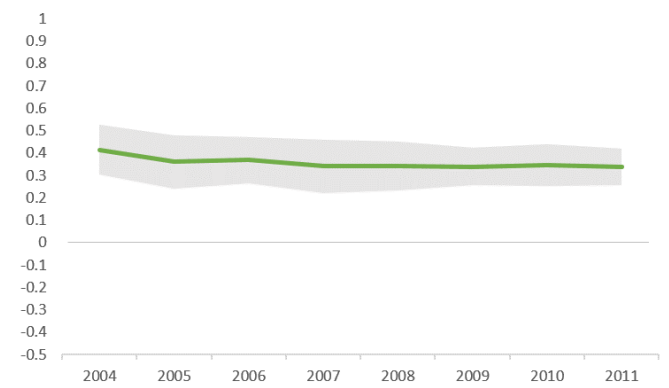

(a) Observed private branch presence

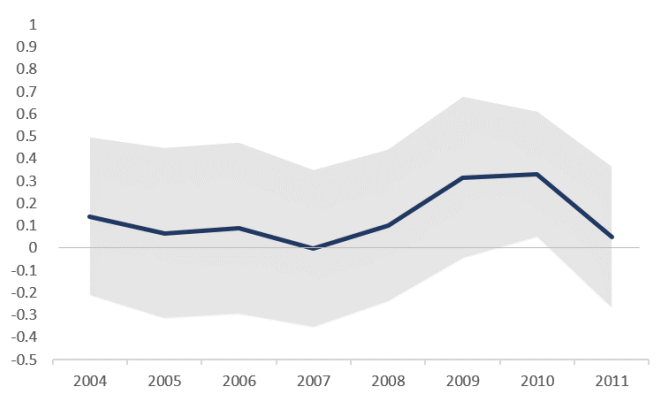

(b) Predicted prob. of private branch

Figure 7 - Plots of coefficients and confidence intervals for $\log$ (creditpc)

Note: Coefficients of cross-section regressions controlled for presence of public bank branches, $\log$ (population), $\log ($ GPDpercapita $)$, positive and negative population growth, elderly, $\log$ (landvalue). Bootstrapped standard errors computed using 100 repetitions. Confidence intervals of $95 \%$ Prepared by the authors.

\subsection{Second stage: Effects of bank branches on credit}

Our objective with this paper is to estimate the impact of bank branches in the local credit market. We first estimate cross-section regressions of $\log$ (creditpercapita) as a function of the presence of private and public banks, controlled for all the characteristics used in the first stage. We use dummies of observed private and public branches in the 1,097 markets for which we have estimates of the complete information model to regress the observed data model. Then we use the estimated probability of private bank branches that results from the model to do the same cross-section regressions. We plot the coefficients and respective 95\% confidence intervals in Figure 7.

The regression with observed data results in a coefficient of approximately 0.4, which would mean that the presence of a private bank branch would lead to an increase of $40 \%$ on credit per capita. The chart shows that it was probably an overestimation of the effect of private banks on credit. The magnitude of the regression coefficients of predicted probability is perceptively smaller with an 0.1 average. Since the probability variable was built from another regression and errors are bootstrapped, they tend to be larger and, therefore, most coefficients are not different from zero, considering the confidence intervals of $95 \%$, except for $2010^{1}$. In that year the point estimate is of 0.33 (33\% raise in credit per capita if there are private banks), which can vary from 0.051 to 0.609 .

Taking the point-estimate and the average of credit per capita in municipalities with no private bank branches, we can estimate the increase in credit per capita due to the introduction of banking. The introduction of a bank branch in municipalities with zero private banks in 2004 would increase credit per capita from $\mathrm{R} \$ 1,401$ to $\mathrm{R} \$ 1,599$ or $14,1 \%$.

$\overline{1}$ The coefficient for 2009 is nearly significant. If we considered $85 \%$ confidence level it would be different from zero. 
In 2010, the credit market was more developed, with a higher per capita base, even in markets with no branches: $\mathrm{R} \$ 2,761$ of credit per capita. Spreading banking into these communities would elevate this number in $33 \%$, reaching $\mathrm{R} \$ 3,672$ of credit per capita in 2011 values. In the last year of our sample the point-estimate reduced again and the estimated increase was of $4,8 \%$ over the base of $\mathrm{R} \$ 2,935$, which would mean that if the municipalities in our sample with zero private banks (716 in 2011) got branches, credit per capita in these markets would be of $\mathrm{R} \$ 3,076$ on average. Considering the total population of these markets $(9.720 .574)$, that would mean $\mathrm{R} \$ 1,4$ billion more in credit.

As discussed previously, the model proposed by Bresnahan and Reiss considers complete information and firm homogeneity. Those assumptions are very restrictive, thus we chose to do an additional exercise, using a more general model that considers incomplete information among firms. Since we are mainly interested in the predicted number of firms in each market, we only worry about the reduced form of the model. 



\section{Additional analysis: Entry under incomplete informa- tion}

Since the assumption of complete information is rather strong, in this section, we use a second IO model, less restrictive to predict the number of branches as an alternative to the Bresnahan and Reiss model.

We base our estimations on the work by Sanches, Silva-Junior and Srisuma (2015), who propose a dynamic structural model with incomplete information to determine the drivers of bank entry and the effect of public and private banks on private banks entry.

Since our interest here lies only in the predicted number of branches and not in counterfactual analysis, we use reduced forms of the model proposed by the authors and adapt those models to reflect the number of branches that each bank chooses to enter the market with (Sanches, Silva-Junior and Srisuma (2015) model only the bank's decision to enter the market or not).

Firstly, we adapt their linear probability model from a decision of being active (1) or not (0) to a decision of entering the market with $\mathrm{N}$ branches or not entering (0). That leaves us with the regression specified by Equation 5.1. The number $(N)$ of bank branches a player $j$ chooses to open in a given market $i$ is a function of: (i) the number of branches the player had in the previous period (in this case our time variable is annual), (ii) the number of private and public competitors branches present in $t-1$, (ii) market characteristics (vector $\boldsymbol{X}_{i}^{\boldsymbol{t}}$ ), (iii) a time trend $\mu^{t 1}$, (iv) a market/bank dummy $\mu_{j i}$ and (v) an interaction between the time trend and markets dummies $\mu_{i}^{t}$.

$$
N_{j i}^{t}=\beta_{0}+\beta_{1} N_{j i}^{t-1}+\beta_{2} p u b c o m p N_{i}^{t-1}+\beta_{3} \text { privcomp } N_{i}^{t-1}+\beta_{4} \boldsymbol{X}_{i}^{t}+\mu^{t}+\mu_{j i}+\mu_{i}^{t}+\xi_{j i}^{t}
$$

The municipalities characteristics considered in $\boldsymbol{X}_{\boldsymbol{i}}^{t}$ are: market Payroll, transfers from federal and state governments received by the municipality, local government expenditure and agricultural production value, just like in Sanches, Silva-Junior and Srisuma (2015), they are measures of market size. We model both public and private banks choices through two separate estimations.

The lagged activity of the bank in a given market is a way to measure entry/exit cost for the bank in a dynamic framework. If the bank already has a branch in an specific market

$\overline{1}$ The time trend is modeled as 1 for the first year in our sample, 2 for the second one and so on. 
it is cheaper to choose to maintain it than it would be to open a new branch, due to the sunk costs of entering/exiting the market. The number of competitors will affect profit, thus impacting entry decision as well that is why they are also considered in the equation.

We then use a multinomial Logit to estimate a Conditional Choice Probabilities (CCP) model. Following Sanches, Silva-Junior and Srisuma (2015), since firm entry and exit is not frequent enough in our sample, we have to use pooled data from many markets. Due to the impossibility of introducing fixed effects in non-linear models, we use the resulting fixed effects $\left(\mu_{j i}\right)$ from the linear model as an independent variable in our multinomial Logit specification.

In an additional effort to make markets comparable, we select markets with the same number of potential players. Markets with different numbers of potential players will represent different games between players and, therefore, equilibriums are not directly comparable. We consider that bank $j$ is a potential player in market $i$ if it has been present in $i$ for at least one period since 1900. That is, if $N_{j i}^{t}>0$ for at least one period from 1900 to 2011. The definition of potential market follows the authors and is based on the super efficient estimator proposed by Pesendorfer and Schmidt-Dengler (2003).

We select municipalities with 2 public and 2 private potential players. Our sample has 52 markets that meet these criteria. Our estimation takes into consideration all banks that were active at least once in one of those municipalities. Their choice is conditional in lagged activity, market payroll and fixed effects.

Table 4 presents the results of our first stage for the reduced form of the dynamic model. One notices from the analysis of those results that the lagged activity of the bank in the market is crucial to define if it will be active in period $t$. That indicates that there is high inertia in the number of branches, because apparently the costs of entry/exit are fairly high.

The estimation considers all banks that were active for at least one period between 1995 and $2011^{2}$ in markets with 2 private and 2 public potential players.

2 Since the model is dynamic and there are not a lot of bank entries/exits in the markets considered, we had to use a bigger sample, going further back in time then in our credit sample. The estimation starts in 1995 due to the abnormal movement of banks exits after the stabilization (mentioned in section 2). 
Table 4 - Multinomial Logit results

\begin{tabular}{|c|c|c|}
\hline \multicolumn{3}{|l|}{ Dependent variable: $N_{j i}^{t}$} \\
\hline & $(1)$ & $(2)$ \\
\hline & Private bank branches & State owned bank branches \\
\hline \multicolumn{3}{|l|}{$N=1$} \\
\hline$N_{j i}^{t-1}$ & $\begin{array}{c}6.367^{* * *} \\
(0.357)\end{array}$ & $\begin{array}{c}4.314^{* * *} \\
(0.292)\end{array}$ \\
\hline pubcomp $N_{i}^{t-1}$ & $\begin{array}{c}-1.303^{* * *} \\
(0.266)\end{array}$ & $\begin{array}{l}-0.146 \\
(0.139)\end{array}$ \\
\hline privcomp $N_{i}^{t-1}$ & $\begin{array}{c}0.130 \\
(0.273)\end{array}$ & $\begin{array}{l}-0.460 \\
(0.298)\end{array}$ \\
\hline \multicolumn{3}{|l|}{$N=2$} \\
\hline$N_{j i}^{t-1}$ & $\begin{array}{c}25.718 \\
(91.028)\end{array}$ & $\begin{array}{c}20.856 \\
(139.264)\end{array}$ \\
\hline pubcomp $N_{i}^{t-1}$ & $\begin{array}{c}0.514 \\
(54.415)\end{array}$ & $\begin{array}{c}-6.824 \\
(96.795)\end{array}$ \\
\hline $\operatorname{privcomp}_{i}^{t-1}$ & $\begin{array}{c}1.948 \\
(283.493)\end{array}$ & $\begin{array}{c}16.013 \\
(56.409)\end{array}$ \\
\hline Payroll & Yes & Yes \\
\hline Fixed effects & Yes & Yes \\
\hline Constant & Yes & Yes \\
\hline $\mathrm{N}$ & 1,768 & 1,768 \\
\hline
\end{tabular}

Note: Controlled for Payroll. Estimation for the 52 markets that respected the criteria for number of potential players.

Base outcome: 0. Bootstrap standard errors in parentheses (100 repetitions)

$* \mathrm{p}<0.10,{ }^{* *} \mathrm{p}<0.05,{ }^{* * *} \mathrm{p}<0.01$.

Due to the fact that lagged activity has a high influence on activity in $t$, we chose to use the difference between credit in $t$ and credit in $t-1$ as the dependent variable. This way, the fact that credit is a variable that is also highly affected by the lagged activity wont affect the results. Credit is an inter-temporal variable, individuals use credit as a 
mechanism to smooth changes in income. Naturally the credit portfolio is dependent on time and in developing markets such as Brazil, it accumulates over the years, as seen on Figure 4 above.

We used two specifications one with $\Delta \log ($ credit $)$ and another with $\Delta \log ($ creditpc $)$. We now have four charts for each specification because the incomplete information model permits the modeling of public as well as private bank entry. The results for the sample consisting of 52 markets where we have four potential players ( 2 private and 2 public) are plotted in Figures 8 and 10. The results for the 1,097 markets can be seen in Appendix B.

This time around, even the observed data generates non-significant coefficients, with exception for private branches in 2005 and 2006 (9.3\% and $18.3 \%$ change in delta credit and $14.3 \%$ and $23.6 \%$ in credit per capita, respectively). The estimated effect of observed private branches in the variation of credit and credit per capita would be something between $10 \%$ and $20 \%^{3}$. However, once more, when the values predicted by the model are used, all significance is gone. This result could imply that when the omitted variables are taken out of the equation, the number of bank branches has no effect on credit. That is, just having an active bank branch does not change the local credit market. What drives both the opening of branches and the amount of credit taken is something else that is not observed.

$\overline{3}$ The result for the larger sample does not vary significantly and usually is not different from zero 


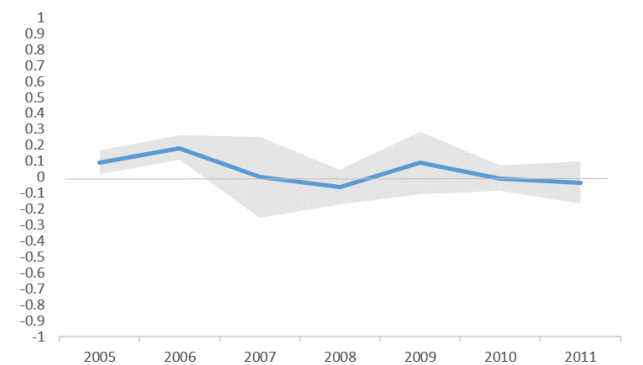

(a) Observed \# of private bank branches

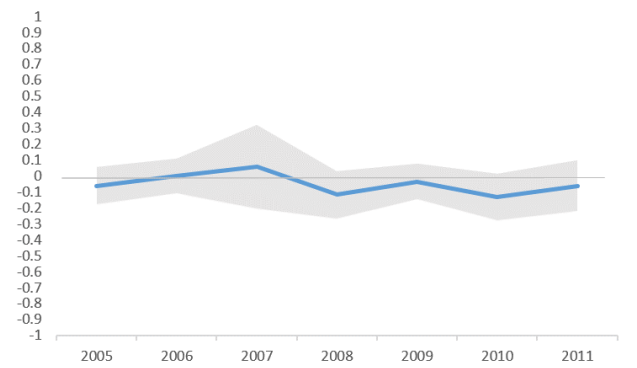

(c) Observed \# of state-owned branches

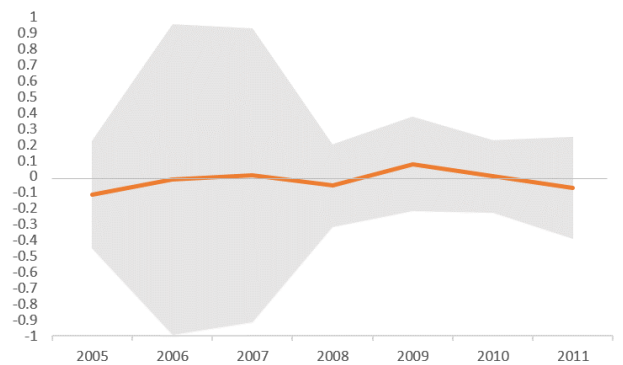

(b) Predicted \# of private branches

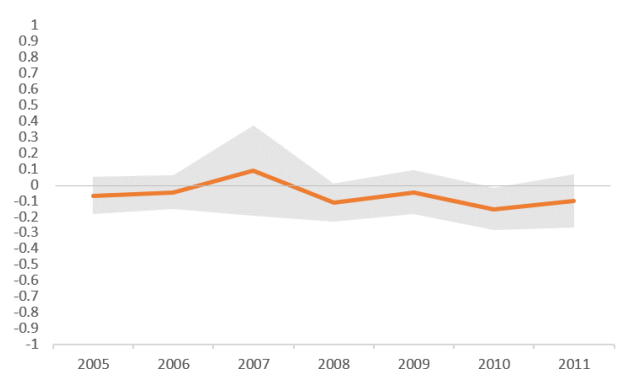

Figure 8 - Plots of coefficients and confidence intervals for $\Delta \log ($ credit) for the restricted sample

Note: Coefficients of cross-section regressions controlled for $\log ($ Payroll). Bootstrapped standard errors computed using 100 repetitions. Prepared by the authors.

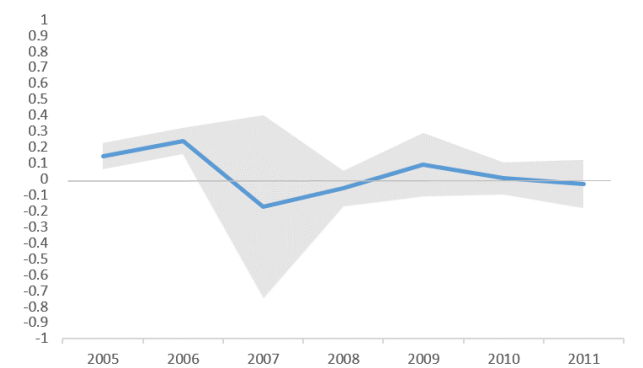

(a) Observed \# of private bank branches

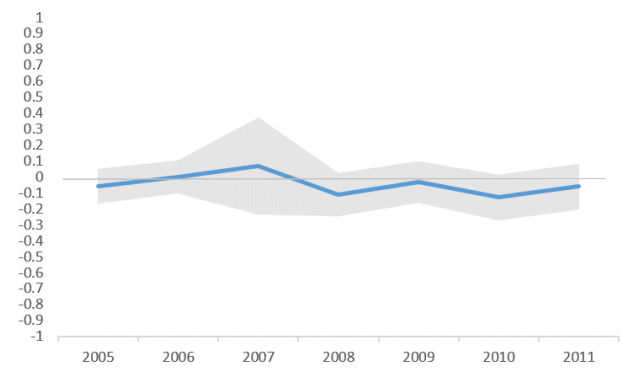

(c) Observed \# of state-owned branches (d) Predicted \# of state-owned branches the restricted sample

Note: Coefficients of cross-section regressions controlled for $\log ($ Payroll $)$. Bootstrapped standard errors computed using 100 repetitions. Prepared by the authors. 
In conclusion, when the bias of the effect of bank branches in credit is reduced through the modeling of firm decision to enter the market, there is no significant influence of bank branches in the variation of credit or credit per capita. 


\section{Concluding Remarks}

Credit has been documented as an important part of economic growth, which can affect consumption, investments and technologies employed on production. Due to this positive effect, finding out credit drivers is relevant to make recommendations and implement public policies.

This study attempted to estimate the impact of bank branches on credit. Since that relation may suffer from endogeneity due to the fact that there may be unobservables that affect both credit and the number of branches in one market, we employed an IO framework to model firm entry and used the predicted probability and number of branches instead of actual observed branches in our second stage estimation.

For our first stage we used an IO model proposed by Bresnahan and Reiss (1991) that assumes firm homogeneity and complete information - for this reason we only modeled private banks entry and considered public banks as exogenous.

We estimated the relation between predicted probability of private bank branches and per capita credit based on the model results. When compared to the least square estimates, the predicted probability of branches shows a much lower impact on credit, that is, it seems that there really was a bias in least square estimates.

Since the variable of interest (probability of having a bank) was built in the first stage and errors are bootstrapped, standard errors are larger in the second stage, reducing significance of our results, which meant that the coefficient could not be considered different from zero with a $95 \%$ confidence interval most of the times. The analysis of the point-estimates shows that the growth in credit would be relevant in years when the coefficient was different from zero (33\% in 2010) and even when the coefficient is lower as in 2011, the average estimated growth in credit amount would be more than 1 billion reais national-wise.

As an additional analysis, we used a reduced form of a dynamic model estimated on Sanches, Silva-Junior and Srisuma (2015), which allowed for the estimation of both public and private bank decisions separately with less restrictive assumptions, such as, incomplete information. We then used the results to estimate the relation between predicted bank branches and the annual delta of credit and credit per capita based on the second model.

In both the Bresnahan and Reiss model and the additional analysis, the coefficient estimated for predicted data had smaller magnitude and almost always lost significance when compared to the observed data coefficient, which could mean that the relation is 
in fact biased due to omitted variables. When the unobservables are stricken from the estimation, bank branches have close to zero effect on credit.

Our results point to the same direction than Petersen and Rajan (2002), since information technology is more evolved, maybe distance is losing importance. However, in our estimation the standard errors could be higher than normal due to the fact that the variable of interest was also predicted through a regression.

Since the methodology used can have high impact on the results, we suggest that future research in the area test different specifications for the first and second stage so as to confirm the result found. Maybe with other approaches, the results could be more accurate with lower standard errors, which could demonstrate a level of impact of banking in credit. Using our model, the result was much lower than the least square estimation and most of the times were statistically equal to zero. 


\section{References}

AGHION, P.; BOLTON, P. A theory of trickle-down growth and development. The Review of Economic Studies, Oxford University Press, v. 64, n. 2, p. 151-172, 1997.

ASSUNÇÃO, J. Eliminating entry barriers for the provision of banking services: Evidence from 'banking correspondents' in brazil. Journal of Banking $\mathscr{G}$ Finance, Elsevier, v. 37, n. 8, p. 2806-2811, 2013.

BANERJEE, A. V.; DUFLO, E. Poor economics: A radical rethinking of the way to fight global poverty. New York, NY: PublicAffairs, 2011.

BANERJEE, A. V. et al. The miracle of microfinance? evidence from a randomized evaluation. MIT Department of Economics Working Paper. 2014.

BANERJEE, A. V.; NEWMAN, A. F. Occupational choice and the process of development. Journal of political economy, JSTOR, p. 274-298, 1993.

BESLEY, T. Nonmarket institutions for credit and risk sharing in low-income countries. Journal of Economic Perspectives, v. 9, n. 3, p. 115-127, 1995.

BESLEY, T.; COATE, S.; LOURY, G. the economics of rotating savings and credit associations. In: MOOKHERJEE, D.; RAY, D. (Org.). Readings in the theory of economic development. Oxford: Blackwell Publishers, 2001. p. 386-410.

BRESNAHAN, T. F.; REISS, P. C. Entry and Competition in Concentrated Markets. Journal of Political Economy, v. 99, n. 5, p. 977, 1991.

CALDERÓN, C.; LIU, L. The direction of causality between financial development and economic growth. Journal of development economics, Elsevier, v. 72, n. 1, p. 321-334, 2003.

COELHO, C. A.; De Mello, J. M.; REZENDE, L. Do public banks compete with private banks? evidence from concentrated local markets in brazil. Journal of Money, Credit and Banking, Wiley Online Library, v. 45, n. 8, p. 1581-1615, 2013.

COSTA, A. C. A.; De Mello, J. M. Judicial risk and credit market performance: micro evidence from brazilian payroll loans. In: Financial Markets Volatility and Performance in Emerging Markets. [S.1.]: University of Chicago Press, 2008. p. 155-184.

De Mello, J. M. P.; GARCIA, M. G. Bye, bye financial repression, hello financial deepening: The anatomy of a financial boom. The Quarterly Review of Economics and Finance, Elsevier, v. 52, n. 2, p. 135-153, 2012.

DEBAN. Diagnóstico do sistema de pagamentos de varejo do brasil adendo estatístico - 2005. Departamento de Operações Bancárias e de Sistema de Pagamentos (Deban) Banco Central do Brasil, 2005 (visited October 14 ${ }^{\text {th }}$, 2015). Available from Internet: $<$ http://www.bcb.gov.br/htms/spb/Diagnostico-Adendo-2005.pdf >.

DEBAN. Diagnóstico do sistema de pagamentos de varejo do brasil adendo estatístico - 2010. Departamento de Operações Bancárias e de Sistema de Pagamentos (Deban) Banco Central do Brasil, 2010 (visited October 14 ${ }^{\text {th }}$, 2015). Available from Internet: $<$ http://www.bcb.gov.br/htms/spb/Diagnostico-Adendo-2010.pdf $>$. 
DEBAN. Diagnóstico do sistema de pagamentos de varejo do brasil adendo estatístico - 2011. Departamento de Operações Bancárias e de Sistema de Pagamentos (Deban) Banco Central do Brasil, 2011 (visited October 14 ${ }^{\text {th }}$, 2015). Available from Internet: <http://www.bcb.gov.br/htms/spb/Diagnostico-Adendo-2011.pdf >.

FEBRABAN. Pesquisa FEBRABAN de tecnologia bancária 2014. 2014.

FREIXAS, X.; ROCHET, J.-C. Microeconomics of Banking. Cambridge, MA: The MIT Press, 2008.

GHOSH, P.; MOOKHERJEE, D.; RAY, D. Credit rationing in developing countries: an overview of the theory. In: MOOKHERJEE, D.; RAY, D. (Org.). Readings in the theory of economic development. Oxford: Blackwell Publishers, 2001. p. 283-301.

JACK, W.; SURI, T. Mobile money: the economics of m-pesa. NBER Working Paper No. 16721. 2011.

KARLAN, D.; ZINMAN, J. Expanding credit access: Using randomized supply decisions to estimate the impacts. Review of Financial studies, Soc Financial Studies, p. hhp092, 2009.

LA PORTA, R.; LOPEZ-DE-SILANES, F.; SHLEIFER, A. Government ownership of banks. The Journal of Finance, Wiley Online Library, v. 57, n. 1, p. 265-301, 2002.

LEVINE, R. Law, finance, and economic growth. Journal of financial Intermediation, Elsevier, v. 8, n. 1, p. 8-35, 1999.

PANDE, R.; BURGESS, R. Do rural banks matter? evidence from the indian social banking experience. American Economic Review, v. 95, n. 3, p. 780-795, 2005.

PAULSON, A. L.; TOWNSEND, R. M.; KARAIVANOV, A. Distinguishing limited liability from moral hazard in a model of entrepreneurship. Journal of Political Economy, v. 114, n. 1, p. 100-144, 2006.

PESENDORFER, M.; SCHMIDT-DENGLER, P. Identification and estimation of dynamic games. NBER Working Paper No. 9726. 2003.

PETERSEN, M. A.; RAJAN, R. G. Does distance still matter? the information revolution in small business lending. The Journal of Finance, Blackwell Publishing, Inc., v. 57, n. 6, p. 2533-2570, 2002. ISSN 1540-6261.

SANCHES, F. M.; SILVA-JUNIOR, D.; SRISUMA, S. Bank Privatization and Market Structure of the Banking Industry: Evidence from a Dynamic Structural. Working Paper. 2015.

STIGLITZ, J. E.; WEISS, A. Credit rationing in markets with imperfect information. The American economic review, JSTOR, p. 393-410, 1981.

VISARIA, S. Legal reform and loan repayment: The microeconomic impact of debt recovery tribunals in india. American Economic Journal: Applied Economics, American Economic Association, v. 1, n. 3, p. 59-81, 2009. 


\section{A Maps of Brazilian municipalities by number of pri- vate and public bank branches}

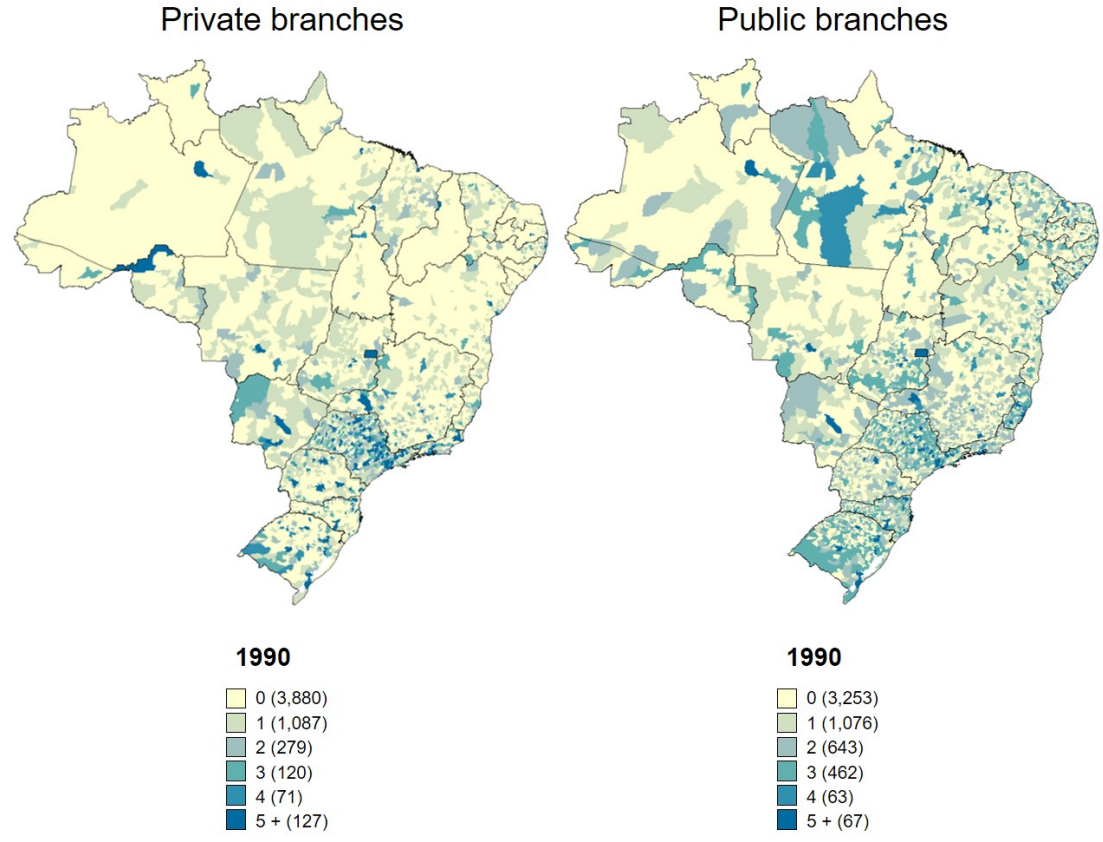

Figure 12 - Brazilian Municipalities by number of private and public bank branches - 1990

Note: data from Brazilian Central Bank (BCB) and shapefiles from The Brazilian Institute of Geography and Statiscs (IBGE). Prepared by the authors. 
Private branches

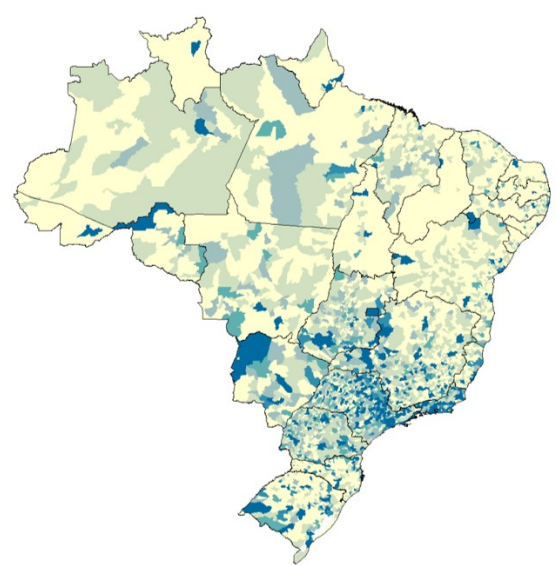

2003

$\begin{aligned} \square & 0(3,289) \\ \square & 1(1,289) \\ \square & 2(415) \\ \square & 3(174) \\ \square & 4(92) \\ & 5+(305)\end{aligned}$
Public branches

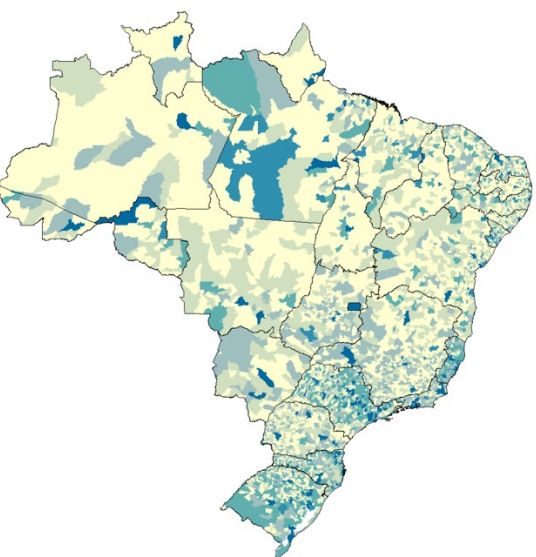

2003

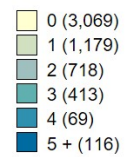

Figure 13 - Brazilian Municipalities by number of private and public bank branches - 2003

Note: data from Brazilian Central Bank (BCB) and shapefiles from The Brazilian Institute of Geography and Statiscs (IBGE). Prepared by the authors.

Private branches

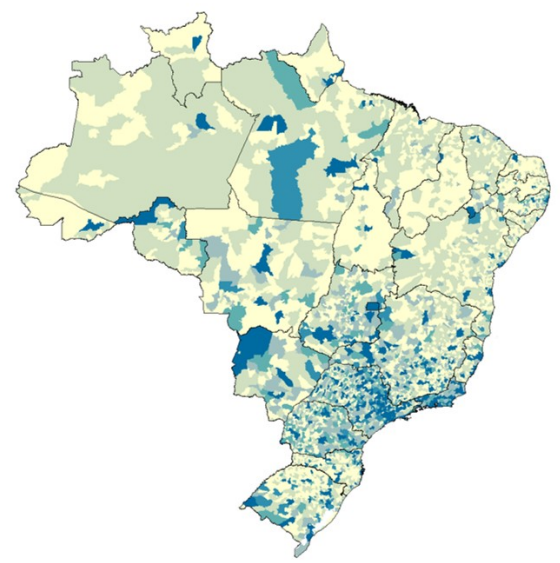

2011

$\square 0(2,914)$

$1(1,461)$
$2(534)$

$3(234)$

$4(96)$
Public branches

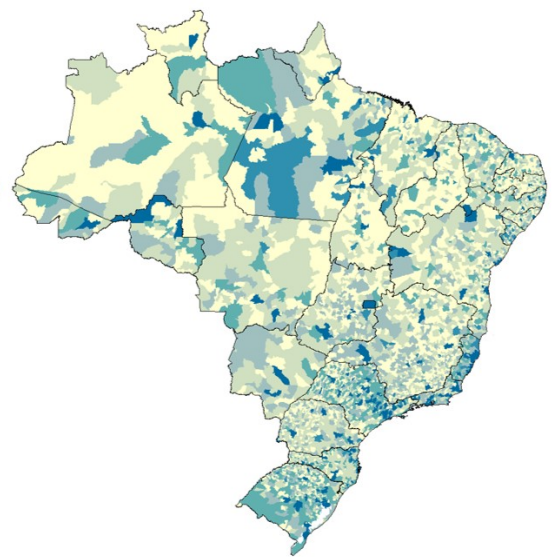

2011

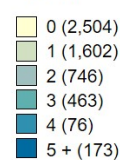

Figure 14 - Brazilian Municipalities by number of private and public bank branches - 2011

Note: data from Brazilian Central Bank (BCB) and shapefiles from The Brazilian Institute of Geography and Statiscs (IBGE). Prepared by the authors. 


\section{B Results for incomplete information model applied to the 1,097 markets sample}

0.2

0.1

0

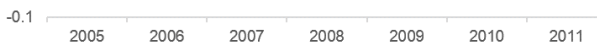

(a) Observed \# of private bank branches 0.2

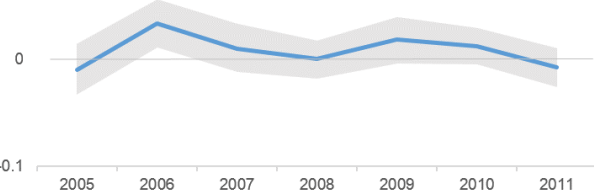

0.2

0.1

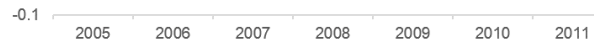

(b) Predicted \# of private branches 0.2

0.1

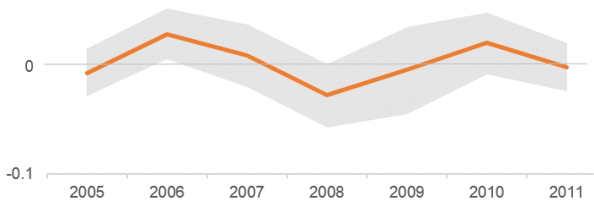

(c) Observed \# of state-owned branches (d) Predicted \# of state-owned branches

Figure 15 - Plots of coefficients and confidence intervals for $\Delta \log ($ credit) for the 1,097 markets sample

Note: Coefficients of cross-section regressions controled for $\log ($ Payroll). Bootstrapped standard errors computed using 100 repetitions. Prepared by the authors. 
0.2

0.1

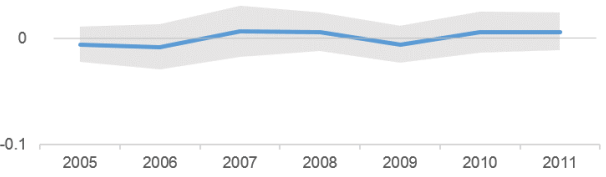

(a) Observed \# of private bank branches 0.2 0.1

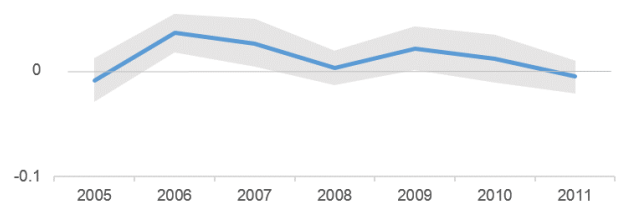

(c) Observed \# of state-owned branches (d) Predicted \# of state-owned branches

Figure 17 - Plots of coefficients and confidence intervals for $\Delta \log ($ creditpc) for the 1,097 markets sample

Note: Coefficients of cross-section regressions controled for $\log ($ Payroll). Bootstrapped standard errors computed using 100 repetitions. Prepared by the authors. 